\title{
CD39 deficiency in murine liver allografts promotes inflammatory injury and immune- mediated rejection
}

\section{Citation}

Yoshida, Osamu, Lei Dou, Shoko Kimura, Shinichiro Yokota, Kumiko Isse, Simon C. Robson, David A. Geller, and Angus W. Thomson. 2015. "CD39 deficiency in murine liver allografts promotes inflammatory injury and immune-mediated rejection." Transplant immunology 32 (2): 76-83. doi:10.1016/j.trim.2015.01.003. http://dx.doi.org/10.1016/j.trim.2015.01.003.

\section{Published Version}

doi:10.1016/j.trim.2015.01.003

\section{Permanent link}

http://nrs.harvard.edu/urn-3:HUL.InstRepos:26318620

\section{Terms of Use}

This article was downloaded from Harvard University's DASH repository, and is made available under the terms and conditions applicable to Other Posted Material, as set forth at http:// nrs.harvard.edu/urn-3:HUL.InstRepos:dash.current.terms-of-use\#LAA

\section{Share Your Story}

The Harvard community has made this article openly available.

Please share how this access benefits you. Submit a story.

Accessibility 


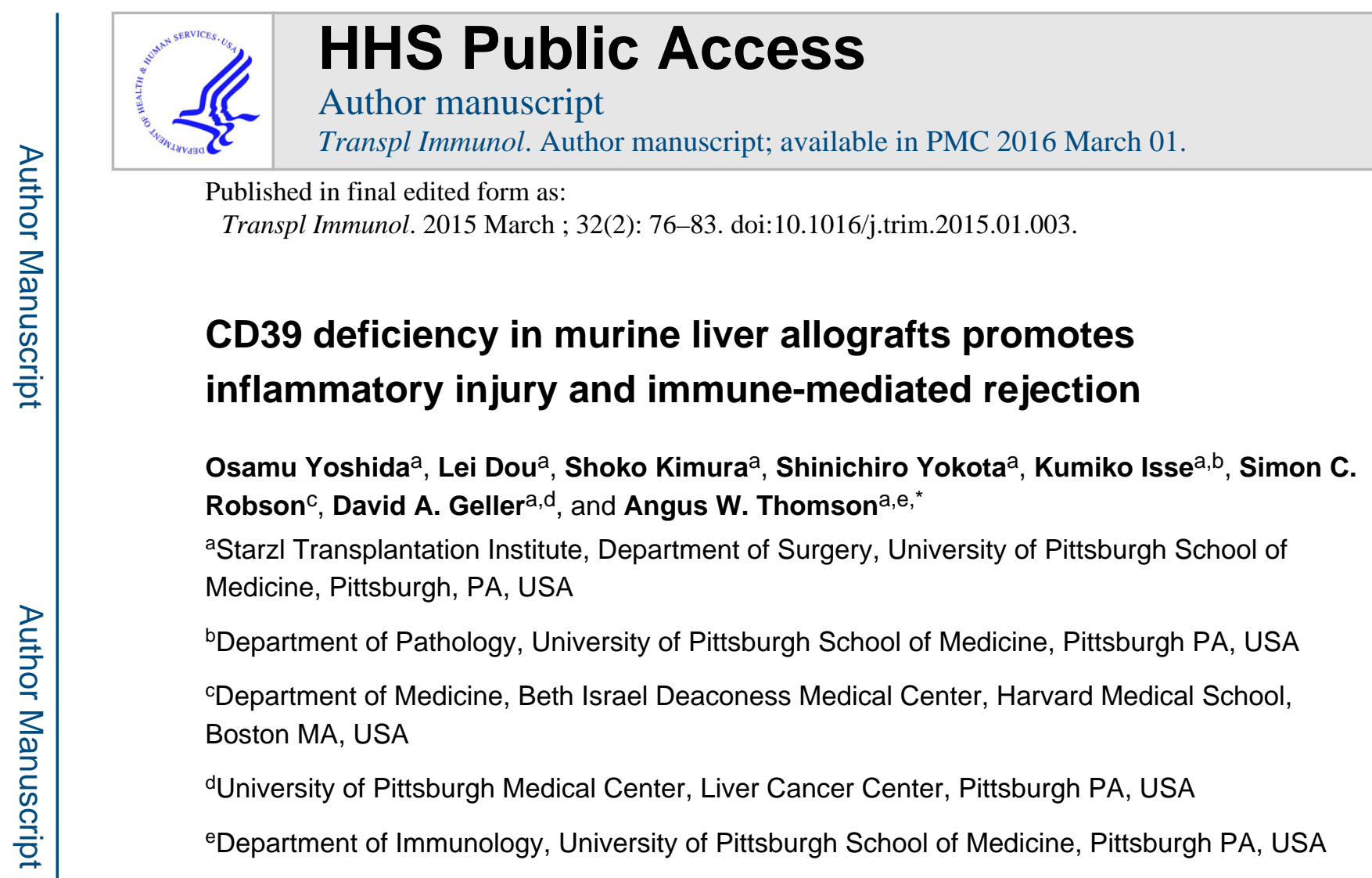

\begin{abstract}
Adenosine triphosphate (ATP), an essential metabolic energy source, is released following cell apoptosis or necrosis. It acts as a damage-associated molecule pattern to stimulate innate immune cells. The ectonucleotidase CD39 regulates immune activation by hydrolysis of extracellular ATP. We have shown previously that CD39 expression by donor livers helps protect syngeneic grafts with extended ( $24 \mathrm{hr}$ ) cold preservation time from ischemia reperfusion injury. Given its immune regulatory properties, we hypothesized that CD39 expression in donor livers might modulate transplant tolerance that occurs following mouse allogeneic liver transplantation (LTx). Livers from C57BL/6 (B6) wild-type (WT) or CD39 KO mice were transplanted into normal C3H recipients with minimal (approximately $1 \mathrm{hr}$ ) cold ischemia. Serum alanine aminotransferase levels at day 4 post LTx were significantly higher in animals given CD39KO compared with WT livers. Moreover, IFN- $\gamma$ production by liver-infiltrating $C D 8^{+} \mathrm{T}$ cells at day 4 was significantly higher in CD39KO than in WT grafts. Furthermore, splenic T cells from CD39KO liver recipients exhibited greater proliferative responses to donor alloantigens than those from mice given WT grafts. By contrast, there was a concomitant significant reduction in the frequency of regulatory $\mathrm{T}$ cells (Treg) in CD39KO than in WT livers. Whereas WT liver allografts survived > 100 days, no CD39KO grafts survived beyond 40 days (median survival time [MST]: WT: >100 days vs
\end{abstract}

(C) 2015 Published by Elsevier B.V.

This manuscript version is made available under the CC BY-NC-ND 4.0 license.

Correspondence to: Angus W. Thomson, PhD DSc, Starzl Transplantation Institute, University of Pittsburgh School of Medicine, 200 Lothrop Street, BST W1540, Pittsburgh, PA 15261, Tel: 412-624-6392, Fax: 412-624-1172, thomsonaw@upmc.edu.

Publisher's Disclaimer: This is a PDF file of an unedited manuscript that has been accepted for publication. As a service to our customers we are providing this early version of the manuscript. The manuscript will undergo copyediting, typesetting, and review of the resulting proof before it is published in its final citable form. Please note that during the production process errors may be discovered which could affect the content, and all legal disclaimers that apply to the journal pertain.

Conflicts of interest

The authors have nothing to disclose regarding funding or conflict of interest with respect to this article. 
CD39KO: 8 days; $\mathrm{p}<0.01$ ). In addition, soluble CD39 administration significantly prolonged CD39KO liver allograft survival (MST: 27.5 days). These novel data suggest that CD39 expression in liver allografts modulates tissue injury, inflammation, anti-donor effector $\mathrm{T}$ cell responses and Treg infiltration and can suppress transplant rejection.

\section{Keywords}

adenosine triphosphate; CD39; liver allograft; $\mathrm{T}$ cells

\section{Introduction}

The liver performs important metabolic functions, degrades toxic and waste products, and regulates immunity. Impairment of these functions, due to autoimmune liver disorders, viral hepatitis, alcohol or cancer can lead to end-stage liver disease, for which liver transplantation (LTx) is the only therapeutic option. The liver is regarded as a lymphoid organ with a unique constituency of immune cells [1-3] and exhibits inherent tolerogenic properties [3-5] These include oral and portal venous tolerance and allograft acceptance in rodents or pigs, without dependence on any immunosuppressive therapy [6, 7]. Human liver transplant recipients have a relatively low susceptibility to rejection and achieve a comparatively high frequency of successful immunosuppressive drug withdrawal compared with recipients of other organs [5, 8, 9]. Although donor-derived leukocytes [10, 11], donorderived dendritic cells (DC) $[12,13]$, regulatory T cells (Treg) $[14,15]$ and expression of immune regulatory molecules, in particular B7-H1[16] (= programed death ligand-1) and DNA-activating protein of $12 \mathrm{kD}$ (DAP12) [17] on donor cells have been implicated as important factors that promote experimental allograft liver acceptance, mechanisms underlying liver transplant tolerance are still poorly understood.

Adenosine triphosphate (ATP) is essential for cell metabolism and is stored in the cell cytosol. Once released extracellularly, as the result of cell death or injury, extracellular (e)ATP acts as a damage-associated molecular pattern (DAMP) that activates innate immune cells through its receptors, P2X and P2Y $[18,19]$. eATP not only activates eosinophils, neutrophils, macrophages and DC [18], but also recruits these immune cells as a 'find-me' signal [20], eATP concentrations increase at sites of inflammation, contact hypersensitivity [21], tumor growth [22], liver injury [23] and graft-versus-host disease following bone marrow transplantation [24], Furthermore, the eATP/P2 receptor axis is involved in the pathogenesis of organ allograft rejection [25] and P2X7 receptor deficiencies, or inhibition of $\mathrm{P} 2 \mathrm{X} 7$ prolong mouse heart allograft survival [26].

CD39 is an ectonucleotidase and hydrolyzes eATP to maintain homeostatic eATP levels. eATP hydrolysis by CD39 regulates immune cell activation and recruitment [20, 27]. Thus, CD39 contributes to the pathogenesis of infectious diseases [28], cancer [29-31], autoimmune disorders [32-34], and ischemia/reperfusion injury of the heart [35], kidney [36], intestine [37] and liver [38, 39]. We have reported recently [40] that CD39 deficiency exacerbates liver injury after syngeneic LTx with $24 \mathrm{hr}$ cold organ storage. However, the role of CD39 in allogeneic organ transplantation has not been investigated. 
Previously [40], we reported that cell surface costimulatory molecules, production of proinflammatory cytokines and T cell allostimulatory activity are augmented in CD39KO liver conventional myeloid dendritic cells (DC), that are regarded as key instigators and regulators of alloimmunity $[41,42]$. These observations suggest an enhanced potential of CD39KO liver DCs to stimulate host $\mathrm{T}$ cell responses and thus enhanced immunogenicity of CD39-deficient liver allografts. To evaluate the contribution of donor CD39 to liver allograft immunity and survival, we performed orthotopic mouse LTx with minimal cold ischemia time using B6 WT or CD39KO (B6 background) mice as donors and normal $\mathrm{C} 3 \mathrm{H}$ mice as recipients. We examined allograft injury, the immune effector and regulatory $\mathrm{T}$ cell responses elicited and transplant survival. Our data suggest that CD39 expression by donor livers is important for regulation of tissue injury, inflammation, anti-donor immunity and the suppression of liver allograft rejection.

\section{Materials and methods}

\subsection{Mice}

Male C57BL/6 (B6;H-2 $\left.{ }^{\mathrm{b}}\right)$, and $\mathrm{C} 3 \mathrm{H}\left(\mathrm{H} 2^{\mathrm{k}}\right)$ mice (8- to 12-wk old) were purchased from The Jackson Laboratory, Bar Harbor, ME. CD39KO mice (B6 background) were bred from pairs received from the Beth Israel Medical Center, Harvard University, Boston, MA. Animals were maintained in the specific pathogen-free Central Animal Facility of the University of Pittsburgh School of Medicine. Experiments were conducted under an Institutional Animal Care and Use Committee-approved protocol and in accordance with criteria outlined in the "Guide for the Care and Use of Laboratory Animals" prepared by the National Academy of Sciences and published by the National Institutes of Health. Animals were fed a diet of Purina rodent chow (Ralston Purina, St. Louis, MO) and received tap water ad libitum.

\subsection{Reagents}

Complete culture medium comprised RPMI-1640 (BioWhittaker, Walkersville, MD) supplemented with $10 \%$ (v/v) fetal calf serum (Nalgene, Miami, FL), non-essential amino acids, L-glutamine, sodium pyruvate, penicillin-streptomycin, and 2-mercaptoethanol (all from Life Technologies, Gaithersburg, MD). ATP and soluble CD39 (Apyrase) were purchased from Sigma-Aldrich (Sr. Louis, MO).

\subsection{Liver transplantation}

Harvesting and orthotopic transplantation of the liver without hepatic artery reconstruction, were performed as described initially by Qian et al [7] with minor modifications [43]. Liver grafts (WT B6 or CD39KO) were perfused with University of Wisconsin solution via the portal vein, then transplanted into $\mathrm{C} 3 \mathrm{H}$ recipients by anastomosis of the suprahepatic vena cava with a running 10-0 suture and by anastomosis of the portal vein and inferior vena cava using the cuff technique. The bile duct was connected via ligation over the stent. The cold ischemia period consistently lasted approximately $1 \mathrm{hr}$. No immunosuppressive therapy was administered. Graft rejection was determined by host survival and confirmed histologically. In some recipients, apyrase (soluble CD39) was injected i.p. at day 0, 1, 3, 5, 7 post transplant and once a week after day 14.

Transpl Immunol. Author manuscript; available in PMC 2016 March 01. 


\subsection{ALT measurement}

Serum alanine aminotransferase (ALT) levels were quantified as described [44].

\subsection{Allograft histology}

Hematoxylin and eosin-stained tissue sections were graded in a 'blinded' fashion by a transplant pathologist (KI) using the Banff schema for acute liver rejection [45].

\subsection{Flow cytometry}

Hepatic non-parenchymal cells (NPC) and spleen cells were treated with Fc $\gamma \mathrm{R}$-blocking rat anti-mouse $\mathrm{CD} 16 / 32 \mathrm{mAb}(2.4 \mathrm{G} 2)$ to prevent non-specific antibody $(\mathrm{Ab})$ binding. They were then incubated for $30 \mathrm{~min}$ with fluorescein isothiocyanate (FITC)-, phycoerythrin (PE)-, APC-, PE-cyanin (Cy)5-, PE-Cy7-or pacific blue-conjugated monoclonal Abs (mAbs) to detect surface expression of CD3 (145-2C11) CD4 (GK1.5) or CD8 (53-6.7) (all eBioscience, San Diego, CA). For intracellular cytokine staining, cells were fixed with $4 \%$ paraformaldehyde and permeabilized using $0.1 \%$ saponin, then stained with anti-mouse IFN- $\gamma$ Ab (XMG1.2) (BioLegend). For forkhead box p3 (Foxp3) staining, cells were fixed and permeabilized using Foxp3 Fix Perm kit (eBioscience) and stained with anti-Foxp3 $\mathrm{mAb}$ (FJK-16s) (eBioscience). Appropriate Ig isotype controls were obtained from BD Pharmingen (San Diego, CA). Flow analysis was performed using an LSR Fortessa flow cytometer (BD Biosciences) and results expressed as percent positive cells and mean fluorescence intensity (MFI).

\subsection{Real-time reverse-transcription polymerase chain reaction (RT-PCR)}

Messenger RNA (mRNA) expression was quantified by SYBR Green real-time RT-PCR using an ABI-Prism 7000 sequence detection system (PE Applied Biosystems, Foster City, CA) and primers specific for IFN- $\gamma$ (F: 5'-CACGGCACAGTCATTGAAAG-3'; R; 5'TTTTGCCAGTTCCTCCAGAT-3') or $\beta$-actin (F: 5'-AGAGGGAAATCGTGCGTGAC-3'; R: 5'-CAATAGTGATGACCTGGCCGT-3'). The expression of IFN- $\gamma$ was normalized to the expression of $\beta$-actin mRNA using the comparative cycle threshold method.

\subsection{Anti-donor T cell responses}

To assess anti-donor immune responses, T cell-depleted WT B6 splenocytes were used as stimulators and carboxyfluorescein succinimidyl ester (CFSE)-labeled recipient splenocytes as responders. Stimulator and responder cells were co-cultured at 1:1 ratio for 5 days. CFSElabeled T cell proliferation was determined by flow cytometry [17].

\subsection{Statistical analyses}

The significances of differences between means were ascertained using the unpaired Student ' $t$ ' test or Gehan-Breslow-Wilcoxon test using Prism version 5.00 (Graphpad Software, San Diego, CA). Values of $\mathrm{p}<0.05$ were considered significant. 


\section{Results}

\subsection{The immune cell repertoire in CD39KO mouse livers}

As reported previously [40], no significant differences were observed between CD39KO and WT livers in the absolute numbers of all innate and adaptive immune cells examined (i.e. CD4, CD8, Treg, NKT, NK, B, conventional myeloid DC, plasmacytoid DC and Kupffer cells). Furthermore, there was no significant difference between the groups in the expression of CD4 or CD8 T cell surface activation markers or the proliferation of these cells following their allogeneic stimulation (data not shown). However, conventional myeloid DC from CD39 KO mice displayed enhanced MHC class II and costimulatory molecule expression, increased pro-inflammatory cytokine production in response to LPS \pm ATP stimulation, and enhanced allogeneic T cell stimulatory activity in MLR. We also observed a reduction in suppressive function of Treg isolated from CD39KO livers (data not shown).

\subsection{CD39KO liver allografts exhibit more marked inflammatory injury than wt allografts}

To examine the role of CD39 expression by donor tissue in mouse MHC-mismatched orthotopic liver transplantation, we grafted WT or CD39KO livers into normal C3H recipients and euthanized the recipients at day 4 after LTx. Acute rejection was assessed by serum ALT levels and histological grading (Banff criteria). As shown in Figure 1A, CD39KO liver recipients exhibited significantly higher circulating ALT levels compared

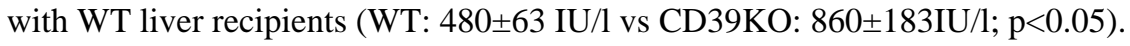

Histologically, allografts lacking CD39 displayed more severe inflammatory liver injury than WT allografts as determined by Banff Schema (Figure 1B \& 1C). These results indicate that CD39 expression by donor livers is involved in regulation of acute liver allograft rejection.

\subsection{Treg are reduced significantly in CD39KO liver allografts}

To explore mechanisms underlying the enhanced acute rejection of CD39KO livers, we examined immune cell populations in allografts and recipient spleens at day 4 after LTx. Treg are important for the regulation of alloimmune responses [46], including 'spontaneous' liver transplant tolerance. $[14,15]$ We found that the incidence of Treg was reduced significantly in CD39KO compared with WT grafts (WT: $36.7 \pm 6.24 \%$ vs CD39KO: $28.9 \pm 2.7 \%$; $\mathrm{p}<0.05$ ) (Figure $2 \mathrm{~A} \& \mathrm{~B}$ ). Similarly to the liver grafts, spleens of CD39KO transplant recipients displayed significantly less Treg than those of WT livers (WT: $30.0 \pm 3.92 \%$ vs CD39KO: $24.9 \pm 1.3 \%$; $<<0.05$ ) (Figure $2 \mathrm{~A} \& \mathrm{C}$ ). These data suggest that reduced Treg in CD39KO liver transplants may be causally related to the more severe inflammation and tissue injury observed in these grafts.

\subsection{CD39KO liver allografts exhibit enhanced IFN- $\gamma$ gene expression and CD8 ${ }^{+}$IFN- $\gamma^{+}$T cells}

While Treg may protect livers from immune-mediated rejection, effector T cells are important mediators of the acute rejection response. IFN- $\gamma$ is a key cytokine released by effector $\mathrm{T}$ cells that mediates graft rejection. Thus, we measured the expression of IFN- $\gamma$ in liver allografts and IFN- $\gamma$ expression by effector T cells following LTx. CD39KO allografts 
displayed significantly higher IFN $-\gamma$ gene expression compared with WT grafts at day 4 after LTx (WT: $88.4 \pm 34.1$ vs CD39KO: 179.9 $\pm 73.1 ; \mathrm{p}<0.05$ ) (Figure 3A). Moreover, the incidence of $\mathrm{CD}^{+} \mathrm{IFN}-\gamma^{+}$cells was increased significantly in CD39KO livers compared with WT grafts (WT: $38.8 \pm 1.7 \%$ vs CD39KO: $46.6 \pm 4.4 \%$; $\mathrm{p}<0.05$ ) (Figure $3 \mathrm{~B} \& \mathrm{C}$ ).

\subsection{CD39KO liver allograft recipients display enhanced anti-donor $\mathrm{T}$ cell proliferative responses}

To further evaluate anti-donor T cell responses, we harvested host splenocytes at day 4 after LTx, and stimulated them ex vivo with T cell-depleted donor splenocytes. Although T cells from both WT and CD39KO liver recipients displayed proliferation after ex vivo restimulation in CFSE-MLR, T cells from CD39KO liver recipients exhibited greater proliferation (CD3; WT: $27.2 \pm 2.6 \%$ vs CD39KO: $36.3 \pm 2.5 \%$; $<<0.05$, CD4; WT: $22.4 \pm 2.4 \%$ vs CD39KO: $30.1 \pm 2.2 \%$; $<<0.05$, CD8; WT: $30.6 \pm 3.2 \%$ vs CD39KO: $42.9 \pm 3.4 \% ; \mathrm{p}<0.05$ ) (Figure $4 \mathrm{~A} \& \mathrm{~B}$ ). These results demonstrate that CD39KO liver grafts induce stronger systemic anti-donor T cell-mediated immune responses than WT livers.

\subsection{CD39 deficiency in donor livers breaks allograft tolerance}

Mouse WT liver allografts are accepted without immunosuppressive therapy.[7] We determined WT and CD39KO liver allograft survival to assess the impact of CD39 deficiency in donor tissue on mouse liver transplant tolerance. All of the WT liver grafts survived $>100$ days (Figure 5), whereas none of the CD39KO liver recipients survived beyond 40 days post LTx (MST: WT: $>100 \mathrm{~d}$ vs CD39KO: 8d; p<0.01). Furthermore, when we administered apyrase (soluble CD39) as described in the Materials and Methods, CD39KO liver graft survival was prolonged significantly (MST: CD39KO + apyrase 27.5d vs CD39KO; $\mathrm{p}<0.05$ ) (Figure 5). These data indicate that CD39 plays an important role in promotion of mouse allogeneic liver graft survival.

\section{Discussion}

LTx is the only treatment available for patients with end-stage liver disease.

Immunosuppressive drug therapy is required to prevent rejection. Minimization or complete withdrawal of immunosuppressive agents without rejection is an important clinical goal [47, 48]. Importantly, 25-30\% of stable LTx patients can be withdrawn from immunosuppression,- a frequency that is not attainable with other transplanted organs $[8,9]$. Understanding the mechanism(s) of LTx tolerance in both humans and animal models may lead to the development of new approaches to promote tolerance to the liver and other organ allografts.

CD39 is an immunoregulatory molecule, since it hydrolyzes eATP,- a DAMP that activates innate immune cells to generate adenosine that regulates immune responses [49, 50]. Its expression by endothelial cells and leukocytes reduces inflammatory cell trafficking, with consequent reduction in tissue injury following ischemia [51]. We have reported recently [40] that human or mouse conventional liver DC express relatively high levels of cell surface CD39 (compared with DC from secondary lymphoid tissue or blood) and hydrolyze eATP efficiently to generate adenosine. Furthermore, CD39 deficiency is associated with a

Transpl Immunol. Author manuscript; available in PMC 2016 March 01. 
more mature liver DC phenotype and CD39 expression by liver DC plays an important role in regulating the pathogenesis of liver cold I/R injury after syngeneic liver transplantation [40]. In these I/R injury studies using a syngeneic transplant model, an extended cold preservation time of $24 \mathrm{hr}$ was used and liver enzymes and graft histology were examined 6 hr posttransplant. In the present study, in which we hypothesized that CD39 might contribute to liver allograft tolerance after LTx, ischemia time was limited to $1 \mathrm{hr}$ and graft injury and histology were examined 4 days post-transplant. Under these latter conditions of minimal preservation time, liver enzyme levels decrease rapidly and markedly within 2-3 days of transplantation [52]. In keeping with our hypothesis, CD39KO liver grafts displayed more severe inflammatory injury than those from WT donors and broke the allograft tolerance observed in WT graft recipients in the absence of any immunosuppressive therapy. Furthermore, sCD39 administration partially reversed allograft rejection in CD39KO liver recipients. Whether further improvement in allograft survival might be achieved by more frequent administration of sCD39 (once per week) after day 14 post-transplant will be addressed in future experiments. It would also be of interest to test the capacity of WT liver $\mathrm{mDC}$, injected after transplantation, to affect alloimmunity and graft survival.

Our results suggest that eATP contributes to the pathogenesis of acute liver rejection and that CD39 expression on donor cells is important in prevention of allograft rejection. Administration of sCD39, however, did not restore tolerance. Other mechanisms that are not restored by sCD39 may promote indefinite liver allograft survival. While CD39 hydrolyzes eATP into eAMP, CD73 hydrolyzes eAMP into adenosine. Thus CD39 is not fully responsible for adenosine generation from eATP. We speculate that while sCD39 hydrolyzes eATP after LTx, but does not maximize generation of adenosine, both sCD39 and sCD73 may be more effective in reducing liver injury and promoting allograft survival.

Hepatocytes contain ATP in the cell cytosol and release ATP into the extracellular environment during injury/cell death. eATP stimulates immune cells, including neutrophils, $\mathrm{T}$ cells, macrophages and DC and enhances immune reactivity. We have shown [40] that ATP induces liver antigen-presenting cell (DC) maturation and pro-inflammatory cytokine production and enhances their ability to induce allogeneic $\mathrm{T}$ cell proliferation. Moreover, we found that CD39KO liver conventional DC exhibited stronger allogeneic T cell stimulatory capacity and enhanced ability to induce $\mathrm{CD} 8^{+} \mathrm{IFN}-\gamma^{+} \mathrm{T}$ cells in allogeneic MLR. Another molecule expressed by DC (and also by NK cells) that regulates liver DC maturation, migration and T cell allostimulatory function is the transmembrane adaptor protein DAP12. Livers that lack DAP12 also break murine liver transplant tolerance [17].

We speculate that eATP concentrations remain elevated in CD39KO grafts after LTx because of markedly reduced ATP hydrolysis in the absence of CD39. Further, more mature CD39KO donor liver APC are likely to be activated by unhydrolyzed eATP. These activated and thus more mature donor-derived CD39KO liver DC, are capable of migration to secondary lymphoid organs, priming of host naïve $\mathrm{T}$ cells via direct allorecognition and induction of more $\mathrm{CD} 8{ }^{+} \mathrm{IFN}-\gamma^{+} \mathrm{T}$ cells and thus stronger anti-donor effector $\mathrm{T}$ cell responses. Indeed, we found that CD39KO livers were more efficient at sensitizing their hosts since splenic $\mathrm{T}$ cells from CD39KO liver recipients showed greater anti-donor $\mathrm{T}$ cell proliferative responses than those from WT recipients after ex vivo re-stimulation with 
donor cells. Since eATP is also known to activate host T cells via P2X7R in heart graft recipients [25, 26], we suggest that donor-reactive $\mathrm{T}$ cells that infiltrate $\mathrm{CD} 39 \mathrm{KO}$ liver allografts may be further activated by unhydrolyzed eATP, resulting in more severe liver injury.

Treg regulate immune responses and contribute to liver allograft tolerance [14]. In the mouse model of allogeneic liver transplantation, Treg increase in the graft after transplantation, while Treg depletion breaks tolerance [15]. In this study, we found that following transplantation, CD39KO allografts contained less Treg compared to WT grafts. While we consider that graft injury due to $1 \mathrm{hr}$ cold ischemia is substantially diminished by the time that the host immune response and Treg proportions can be measured, we cannot rule out entirely a contribution of graft injury or systemic inflammation to the observed changes in Treg or IFN- $\gamma$-producing effector cells. We have not determined the mechanism underlying reduced Treg in CD39KO allografts, but our preliminary data suggest that CD39KO liver DC induce less Treg in primary MLR compared with WT liver DC (data not shown). Thus, skewing of Th1 responses, not Treg, by CD39KO donor-derived liver DC in lymphoid tissue might explain this finding.

\section{Conclusion}

We demonstrate that in mice, CD39KO livers break murine allograft tolerance, associated with enhanced graft injury, inflammation, intra-graft IFN- $\gamma$ expression and $\mathrm{CD} 8^{+} \mathrm{IFN}-\gamma^{+} \mathrm{T}$ cells, reduced Treg and stronger anti-donor T cell proliferative responses. Furthermore, sCD39 administration partially reverses acute rejection in CD39KO liver recipients. Thus, CD39 appears to be an important molecule for promotion of liver allograft survival, with potential for therapeutic application in transplantation and other immune-mediated hepatic inflammatory disorders.

\section{Acknowledgements}

Supported by National Institutes of Health grant P01AI81678 (AWT). OY was supported by an American Society of Transplantation Basic Science Fellowship and by a nonconcurrent NIH T32 AI74490 Research Training Fellowship

\section{Abbreviations}

$\begin{array}{ll}\text { Ab } & \text { antibody } \\ \text { Ag } & \text { antigen } \\ \text { ALT } & \text { alanine aminotransferase } \\ \text { APC } & \text { antigen-presenting cell(s) } \\ \text { ATP } & \text { adenosine triphosphate } \\ \text { DAMP } & \text { damage-associated molecular pattern } \\ \text { DC } & \text { dendritic cell(s) } \\ \text { LTx } & \text { liver transplantation }\end{array}$




$\begin{array}{ll}\text { MAMP } & \text { microbe-associated molecular pattern } \\ \text { MHC } & \text { major histocompatibility complex } \\ \text { MLR } & \text { mixed leukocyte reaction } \\ \text { Treg } & \text { regulatory T cell(s) } \\ \text { WT } & \text { wild-type }\end{array}$

\section{References}

1. Crispe IN. The liver as a lymphoid organ. Annu Rev Immunol. 2009; 27:147-163. [PubMed: 19302037]

2. Adams DH, Eksteen B, Curbishley SM. Immunology of the gut and liver: a love/hate relationship. Gut. 2008; 57:838-848. [PubMed: 18203807]

3. Thomson AW, Knolle PA. Antigen-presenting cell function in the tolerogenic liver environment. Nat Rev Immunol. 2010; 10:753-766. [PubMed: 20972472]

4. Crispe IN. Hepatic T cells and liver tolerance. Nat Rev Immunol. 2003; 3:51-62. [PubMed: 12511875]

5. Bishop AG, Bertolino PD, Bowen DG, McCaughan GW. Tolerance in liver transplantation. Best practice \& research Clinical gastroenterology. 2012; 26:73-84. [PubMed: 22482527]

6. Calne RY, Sells RA, Pena JR, Davis DR, Millard PR, Herbertson BM, et al. Induction of immunological tolerance by porcine liver allografts. Nature. 1969; 223:472-476. [PubMed: 4894426]

7. Qian S, Demetris AJ, Murase N, Rao AS, Fung JJ, Starzl TE. Murine liver allograft transplantation: tolerance and donor cell chimerism. Hepatology. 1994; 19:916-924. [PubMed: 8138266]

8. Pons JA, Revilla Nuin B, Ramirez P, Baroja Mazo A, Martinez Alarcon L, Robles R, et al. What do we know about the clinical impact of complete withdrawal of immunosuppression in liver transplantation? Transplant Proc. 2012; 44:1530-1532. [PubMed: 22841204]

9. Sanchez-Fueyo A, Strom TB. Immunological tolerance and liver transplantation. J Hepatol. 2004; 41:698-705. [PubMed: 15519640]

10. Bishop GA, Wang C, Sharland AF, McCaughan G. Spontaneous acceptance of liver transplants in rodents: evidence that liver leucocytes induce recipient $\mathrm{T}$-cell death by neglect. Immunol Cell Biol. 2002; 80:93-100. [PubMed: 11869366]

11. Sharland A, Yan Y, Wang C, Bowen DG, Sun J, Sheil AG, et al. Evidence that apoptosis of activated $\mathrm{T}$ cells occurs in spontaneous tolerance of liver allografts and is blocked by manipulations which break tolerance. Transplantation. 1999; 68:1736-1745. [PubMed: 10609951]

12. Thomson AW, Lu L, Murase N, Demetris AJ, Rao AS, Starzl TE. Microchimerism, dendritic cell progenitors and transplantation tolerance. Stem Cells. 1995; 13:622-639. [PubMed: 8590864]

13. Lu L, Rudert WA, Qian S, McCaslin D, Fu F, Rao AS, et al. Growth of donor-derived dendritic cells from the bone marrow of murine liver allograft recipients in response to granulocyte/ macrophage colony stimulating factor. J Exp Med. 1995; 182:379-387. [PubMed: 7629500]

14. Shalev I, Selzner N, Shyu W, Grant D, Levy G. Role of regulatory T cells in the promotion of transplant tolerance. Liver Transpl. 2012; 18:761-770. [PubMed: 22523007]

15. Li W, Kuhr CS, Zheng XX, Carper K, Thomson AW, Reyes JD, et al. New insights into mechanisms of spontaneous liver transplant tolerance: the role of Foxp3-expressing CD25+CD4+ regulatory T cells. Am J Transplant. 2008; 8:1639-1651. [PubMed: 18557727]

16. Morita M, Fujino M, Jiang G, Kitazawa Y, Xie L, Azuma M, et al. PD-1/B7-H1 interaction contribute to the spontaneous acceptance of mouse liver allograft. Am J Transplant. 2010; 10:40 46. [PubMed: 19889124] 
17. Yoshida O, Kimura S, Dou L, Matta BM, Yokota S, Ross MA, et al. DAP12 deficiency in liver allografts results in enhanced donor DC migration, augmented effector T cell responses and abrogation of transplant tolerance. Am J Transplant. 2014; 14:1791-1805. [PubMed: 24935196]

18. Trautmann A. Extracellular ATP in the immune system: more than just a "danger signal". Science signaling. 2009; 2:pe6. [PubMed: 19193605]

19. Eltzschig HK, Sitkovsky MV, Robson SC. Purinergic signaling during inflammation. N Engl J Med. 2012; 367:2322-2333. [PubMed: 23234515]

20. Elliott MR, Chekeni FB, Trampont PC, Lazarowski ER, Kadl A, Walk SF, et al. Nucleotides released by apoptotic cells act as a find-me signal to promote phagocytic clearance. Nature. 2009; 461:282-286. [PubMed: 19741708]

21. Weber FC, Esser PR, Muller T, Ganesan J, Pellegatti P, Simon MM, et al. Lack of the purinergic receptor P2X(7) results in resistance to contact hypersensitivity. J Exp Med. 2010; 207:2609_ 2619. [PubMed: 21059855]

22. Pellegatti P, Raffaghello L, Bianchi G, Piccardi F, Pistoia V, Di Virgilio F. Increased level of extracellular ATP at tumor sites: in vivo imaging with plasma membrane luciferase. PloS one. 2008; 3:e2599. [PubMed: 18612415]

23. Ayata CK, Ganal SC, Hockenjos B, Willim K, Vieira RP, Grimm M, et al. Purinergic P2Y(2) receptors promote neutrophil infiltration and hepatocyte death in mice with acute liver injury. Gastroenterology. 2012; 143:1620-16299. e4. [PubMed: 22974709]

24. Wilhelm K, Ganesan J, Muller T, Durr C, Grimm M, Beilhack A, et al. Graft-versus-host disease is enhanced by extracellular ATP activating P2X7R. Nat Med. 2010; 16:1434-1438. [PubMed: 21102458]

25. Vergani A, Tezza S, Fotino C, Visner G, Pileggi A, Chandraker A, et al. The purinergic system in allotransplantation. Am J Transplant. 2014; 14:507-514. [PubMed: 24433446]

26. Vergani A, Tezza S, D'Addio F, Fotino C, Liu K, Niewczas M, et al. Long-term heart transplant survival by targeting the ionotropic purinergic receptor P2X7. Circulation. 2013; 127:463-475. [PubMed: 23250993]

27. Antonioli L, Pacher P, Vizi ES, Hasko G. CD39 and CD73 in immunity and inflammation. Trends in molecular medicine. 2013; 19:355-367. [PubMed: 23601906]

28. Schulze Zur Wiesch J, Thomssen A, Hartjen P, Toth I, Lehmann C, Meyer-Olson D, et al. Comprehensive analysis of frequency and phenotype of T regulatory cells in HIV infection: CD39 expression of FoxP3 + T regulatory cells correlates with progressive disease. J Virol. 2011; 85:1287-1297. [PubMed: 21047964]

29. Hilchey SP, Kobie JJ, Cochran MR, Secor-Socha S, Wang JC, Hyrien O, et al. Human follicular lymphoma CD39+-infiltrating $\mathrm{T}$ cells contribute to adenosine-mediated $\mathrm{T}$ cell hyporesponsiveness. J Immunol. 2009; 183:6157-6166. [PubMed: 19864600]

30. Mandapathil M, Szczepanski MJ, Szajnik M, Ren J, Lenzner DE, Jackson EK, et al. Increased ectonucleotidase expression and activity in regulatory T cells of patients with head and neck cancer. Clin Cancer Res. 2009; 15:6348-6357. [PubMed: 19825957]

31. Sun X, Han L, Seth P, Bian S, Li L, Csizmadia E, et al. Disordered purinergic signaling and abnormal cellular metabolism are associated with development of liver cancer in Cd39/ENTPD1 null mice. Hepatology. 2013; 57:205-216. [PubMed: 22859060]

32. Fletcher JM, Lonergan R, Costelloe L, Kinsella K, Moran B, O'Farrelly C, et al. CD39+Foxp3+ regulatory T Cells suppress pathogenic Th17 cells and are impaired in multiple sclerosis. $\mathrm{J}$ Immunol. 2009; 183:7602-7610. [PubMed: 19917691]

33. Moncrieffe H, Nistala K, Kamhieh Y, Evans J, Eddaoudi A, Eaton S, et al. High expression of the ectonucleotidase CD39 on T cells from the inflamed site identifies two distinct populations, one regulatory and one memory T cell population. J Immunol. 2010; 185:134-143. [PubMed: 20498355]

34. Grant CR, Liberal R, Holder BS, Cardone J, Ma Y, Robson SC, et al. Dysfunctional CD39(POS) regulatory $\mathrm{T}$ cells and aberrant control of T-helper type 17 cells in autoimmune hepatitis. Hepatology. 2014; 59:1007-1015. [PubMed: 23787765] 
35. Bonner F, Borg N, Burghoff S, Schrader J. Resident cardiac immune cells and expression of the ectonucleotidase enzymes CD39 and CD73 after ischemic injury. PloS one. 2012; 7:e34730. [PubMed: 22514659]

36. Grenz A, Zhang H, Hermes M, Eckle T, Klingel K, Huang DY, et al. Contribution of E-NTPDase1 (CD39) to renal protection from ischemia-reperfusion injury. FASEB J. 2007; 21:2863-2873. [PubMed: 17442731]

37. Guckelberger O, Sun XF, Sevigny J, Imai M, Kaczmarek E, Enjyoji K, et al. Beneficial effects of CD39/ecto-nucleoside triphosphate diphosphohydrolase-1 in murine intestinal ischemiareperfusion injury. Thromb Haemost. 2004; 91:576-586. [PubMed: 14983235]

38. Beldi G, Banz Y, Kroemer A, Sun X, Wu Y, Graubardt N, et al. Deletion of CD39 on natural killer cells attenuates hepatic ischemia/reperfusion injury in mice. Hepatology. 2010; 51:1702-1711. [PubMed: 20146261]

39. Pommey S, Lu B, McRae J, Stagg J, Hill P, Salvaris E, et al. Liver grafts from CD39overexpressing rodents are protected from ischemia reperfusion injury due to reduced numbers of resident CD4(+) T cells. Hepatology. 2013; 57:1597-1606. [PubMed: 22829222]

40. Yoshida O, Kimura S, Jackson EK, Robson SC, Geller DA, Murase N, et al. CD39 expression by hepatic myeloid dendritic cells attenuates inflammation in liver transplant ischemia-reperfusion injury in mice. Hepatology. 2013; 58:2163-2175. [PubMed: 23813862]

41. Lechler RI, Ng WF, Steinman RM. Dendritic cells in transplantation - friend or foe? Immunity. 2001; 14:357-368. [PubMed: 11336681]

42. Morelli AE, Thomson AW. Tolerogenic dendritic cells and the quest for transplant tolerance. Nat Rev Immunol. 2007; 7:610-621. [PubMed: 17627284]

43. Ueki S, Castellaneta A, Yoshida O, Ozaki K, Zhang M, Kimura S, et al. Hepatic B7 homolog 1 expression is essential for controlling cold ischemia/reperfusion injury after mouse liver transplantation. Hepatology. 2011; 54:216-228. [PubMed: 21503939]

44. Castellaneta A, Yoshida O, Kimura S, Yokota S, Geller DA, Murase N, et al. Plasmacytoid dendritic cell-derived IFN-alpha promotes murine liver ischemia/reperfusion injury by induction of hepatocyte IRF-1. Hepatology. 2014; 60:267-277. [PubMed: 24493010]

45. Demetris A, Batts KP, Dhillon AP, Ferrell L, Fung JJ, Geller DA, et al. Banff schema for grading liver allograft rejection: an international consensus document. Hepatology. 1997; 25:658-663. [PubMed: 9049215]

46. Wood KJ, Sakaguchi S. Regulatory T cells in transplantation tolerance. Nat Rev Immunol. 2003; 3:199-210. [PubMed: 12658268]

47. Londono MC, Rimola A, O'Grady J, Sanchez-Fueyo A. Immunosuppression minimization vs. complete drug withdrawal in liver transplantation. J Hepatol. 2013; 59:872-879. [PubMed: 23578883]

48. Feng S. Long-term management of immunosuppression after pediatric liver transplantation: is minimization or withdrawal desirable or possible or both? Curr Opin Organ Transplant. 2008; 13:506-512. [PubMed: 19060534]

49. Junger WG. Immune cell regulation by autocrine purinergic signalling. Nat Rev Immunol. 2011; 11:201-212. [PubMed: 21331080]

50. Ernst PB, Garrison JC, Thompson LF. Much ado about adenosine: adenosine synthesis and function in regulatory T cell biology. J Immunol. 2010; 185:1993-1998. [PubMed: 20686167]

51. Hyman MC, Petrovic-Djergovic D, Visovatti SH, Liao H, Yanamadala S, Bouis D, et al. Selfregulation of inflammatory cell trafficking in mice by the leukocyte surface apyrase CD39. J Clin Invest. 2009; 119:1136-1149. [PubMed: 19381014]

52. Shen K, Zheng SS, Park O, Wang H, Sun Z, Gao B. Activation of innate immunity (NK/IFNgamma) in rat allogeneic liver transplantation: contribution to liver injury and suppression of hepatocyte proliferation. American journal of physiology Gastrointestinal and liver physiology. 2008; 294:G1070-G1077. [PubMed: 18292182] 


\section{Highlights}

- Injury was enhanced in CD39KO compared with wild-type liver allografts posttransplant

- IFN $\gamma$ production by $\mathrm{CD} 8^{+} \mathrm{T}$ cells was enhanced in $\mathrm{CD} 39 \mathrm{KO}$ liver allografts

- The frequency of regulatory T cells was reduced in CD39KO liver allografts

- Median survival time for WT grafts was $>100$ days, but only 8 days for CD39KO grafts

- Soluble CD39 administration significantly prolonged CD39KO liver allograft survival 
A

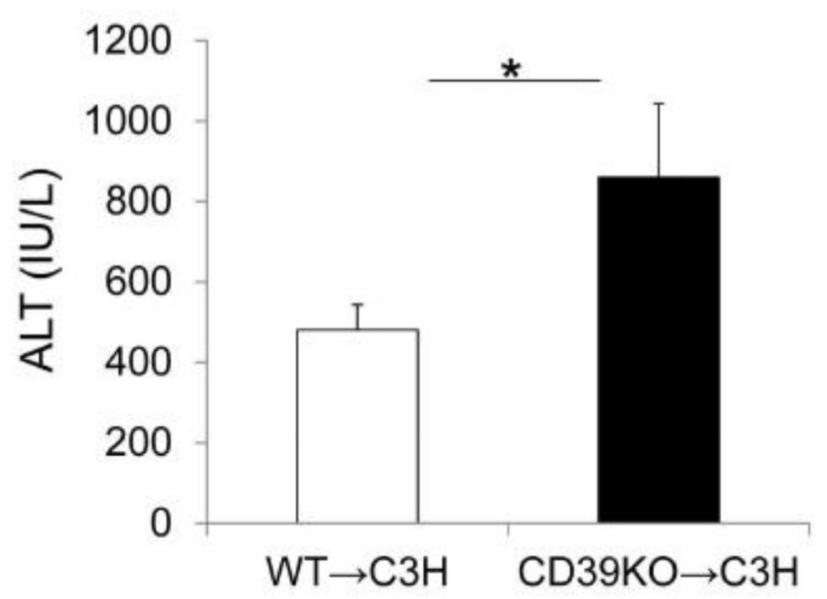

B $\quad \mathrm{B} 6 \mathrm{WT} \rightarrow \mathrm{C} 3 \mathrm{H}$

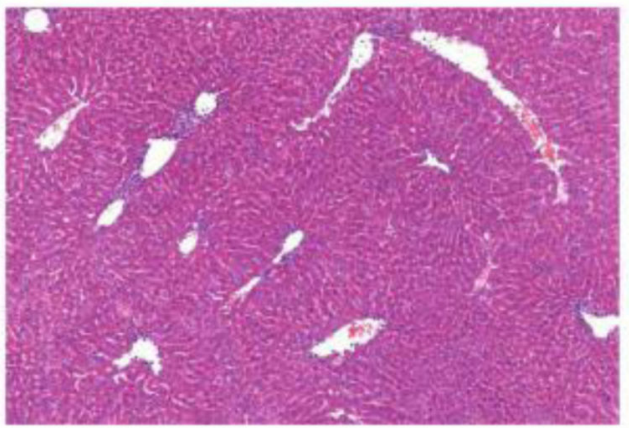

C

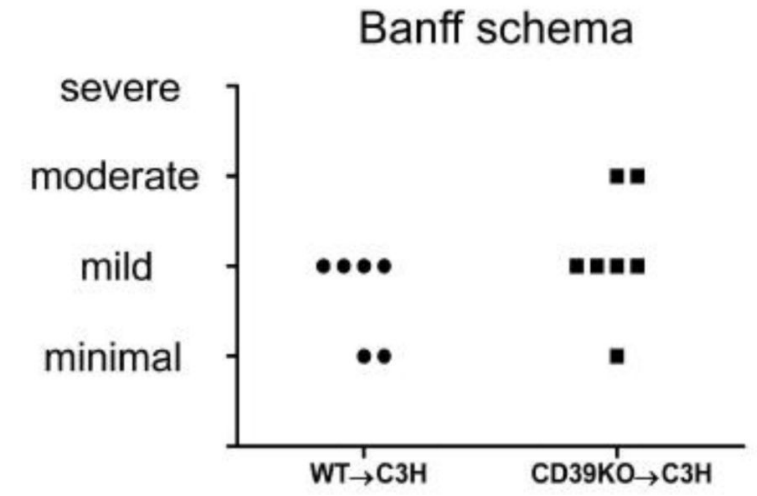

Fig. 1.

CD39KO liver allografts exhibit enhanced inflammatory injury. (A) serum ALT levels were measured at day 4 after orthotopic liver transplantation (LTx) with $1 \mathrm{hr}$ cold preservation time (WT: $n=8$, CD39KO: $n=6$ ), ${ }^{*} \mathrm{p}<0.05$. (B) Representative liver graft histology at day 4 post LTx. (C) Allograft rejection was evaluated by Banff schema (WT: n=5; CD39KO: $\mathrm{n}=6)$. 

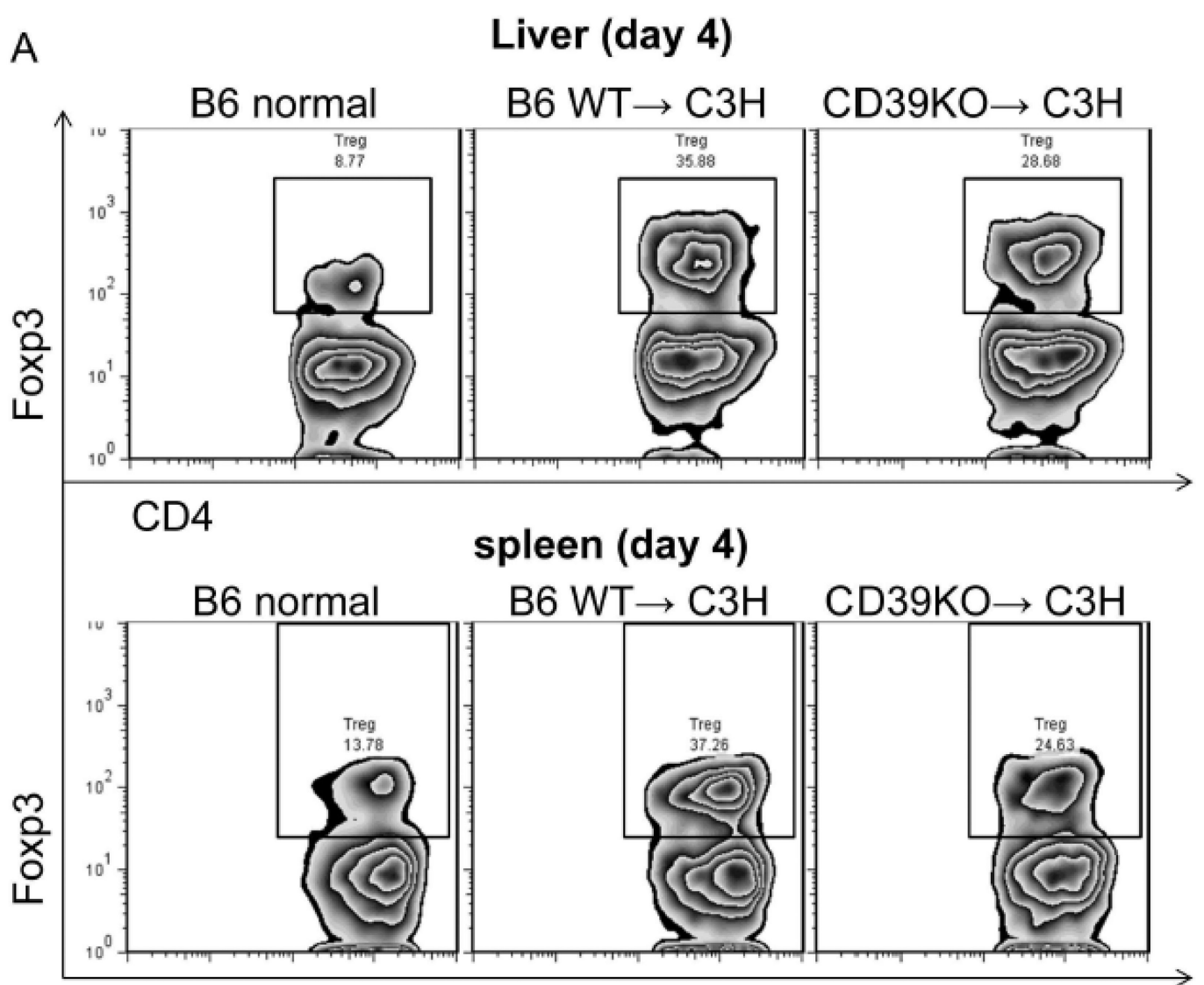

CD4
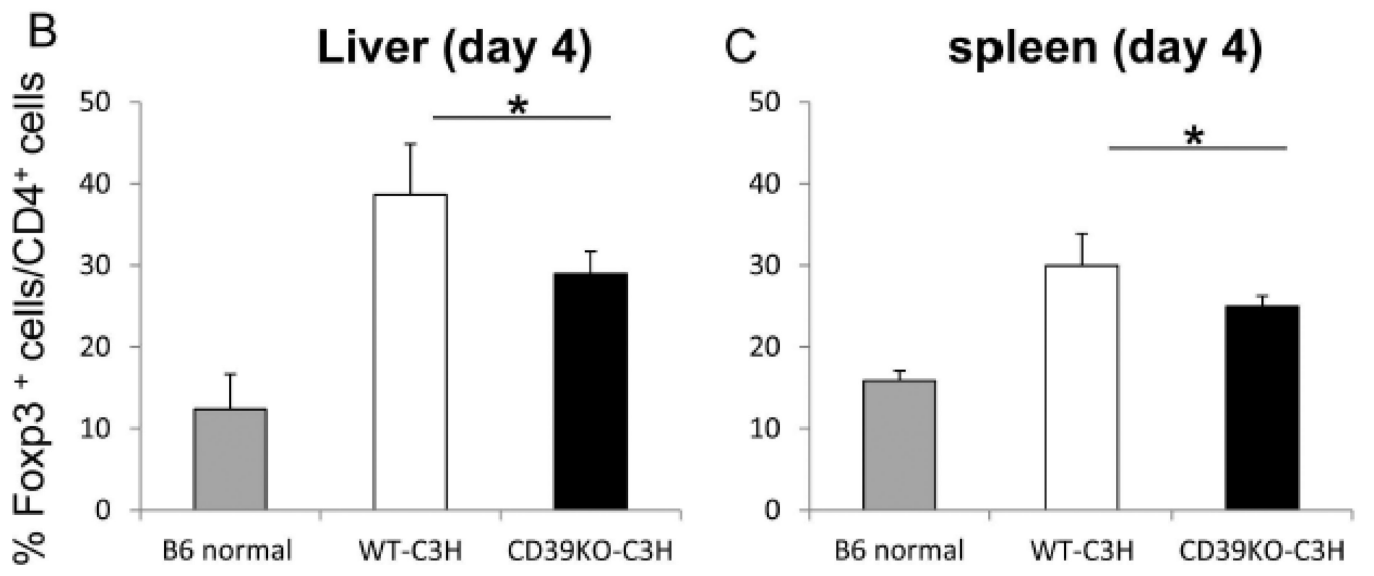

Fig. 2.

CD39KO liver transplant recipients exhibit reduced incidences of intra-graft and splenic Treg. The incidence of Treg in liver allograft $\mathrm{CD}^{+} \mathrm{T}$ cell $(\mathrm{A}, \mathrm{B})$ and recipient spleen $\mathrm{CD}^{+}$ T cell populations $(A, C)$ at day 4 after LTx was determined by flow cytometry $(n=5)$; $* \mathrm{p}<0.05$. 
A

B

C
Liver (day 4) RT-PCR

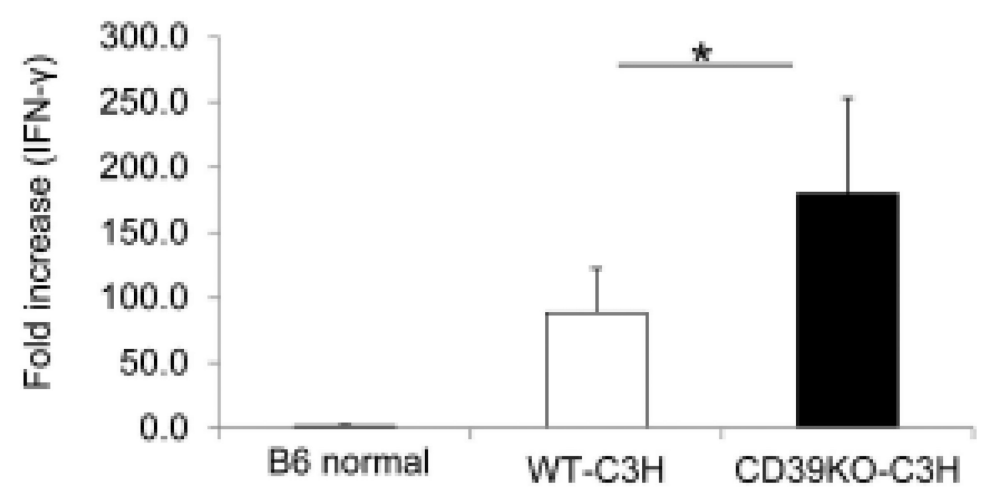

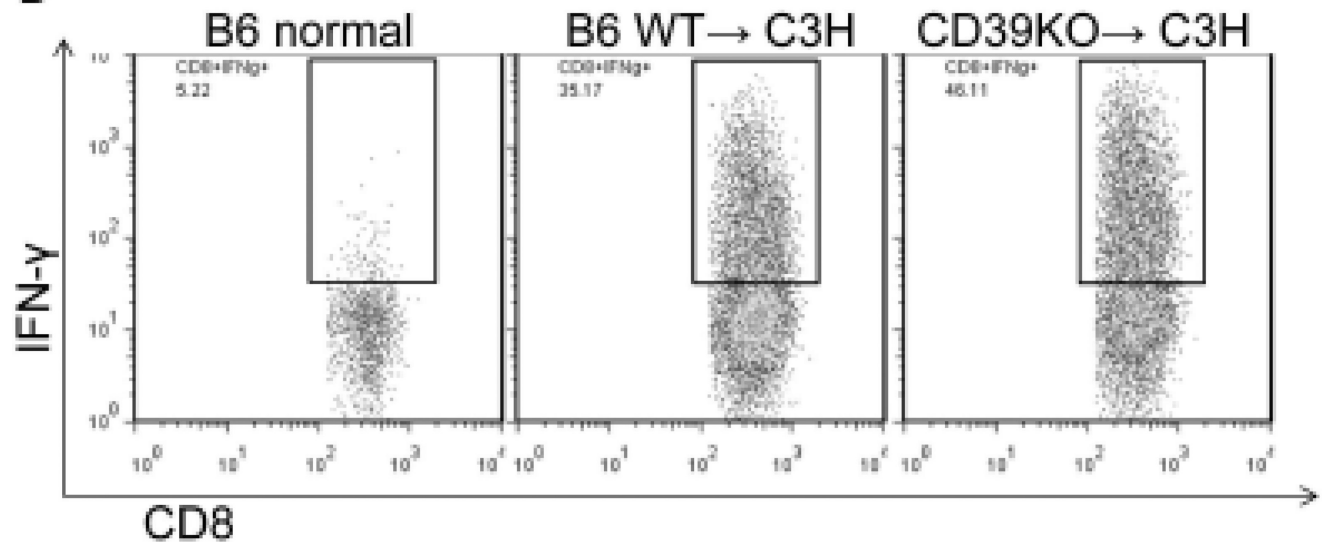

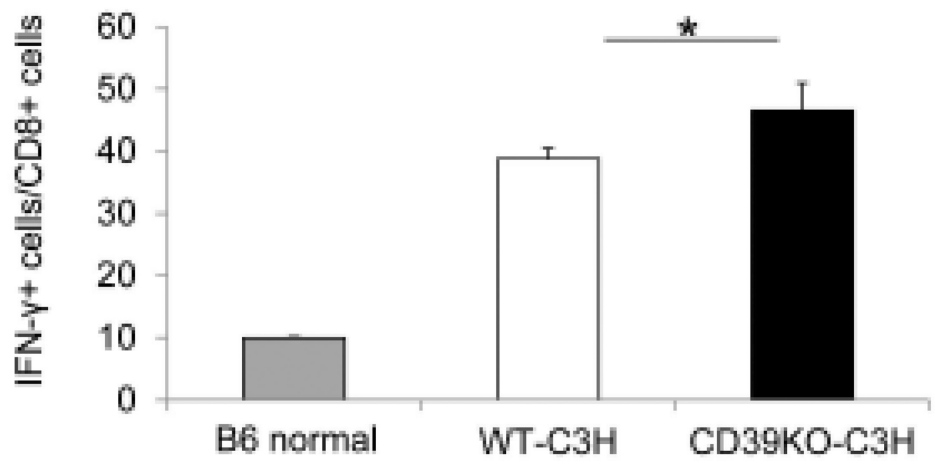

Fig. 3.

More IFN- $\gamma$-producing $\mathrm{CD}^{+} \mathrm{T}$ cells are observed in CD39KO liver allografts. The expression of IFN- $\gamma$ in liver allografts 4 days after LTx was measured by RT-PCR (A). The incidence of IFN $-\gamma^{+} \mathrm{CD}^{+} \mathrm{T}$ cells in liver allografts at day 4 post LTx was examined by flow cytometry $(B, C)(n=4) ; * p<0.05$. 


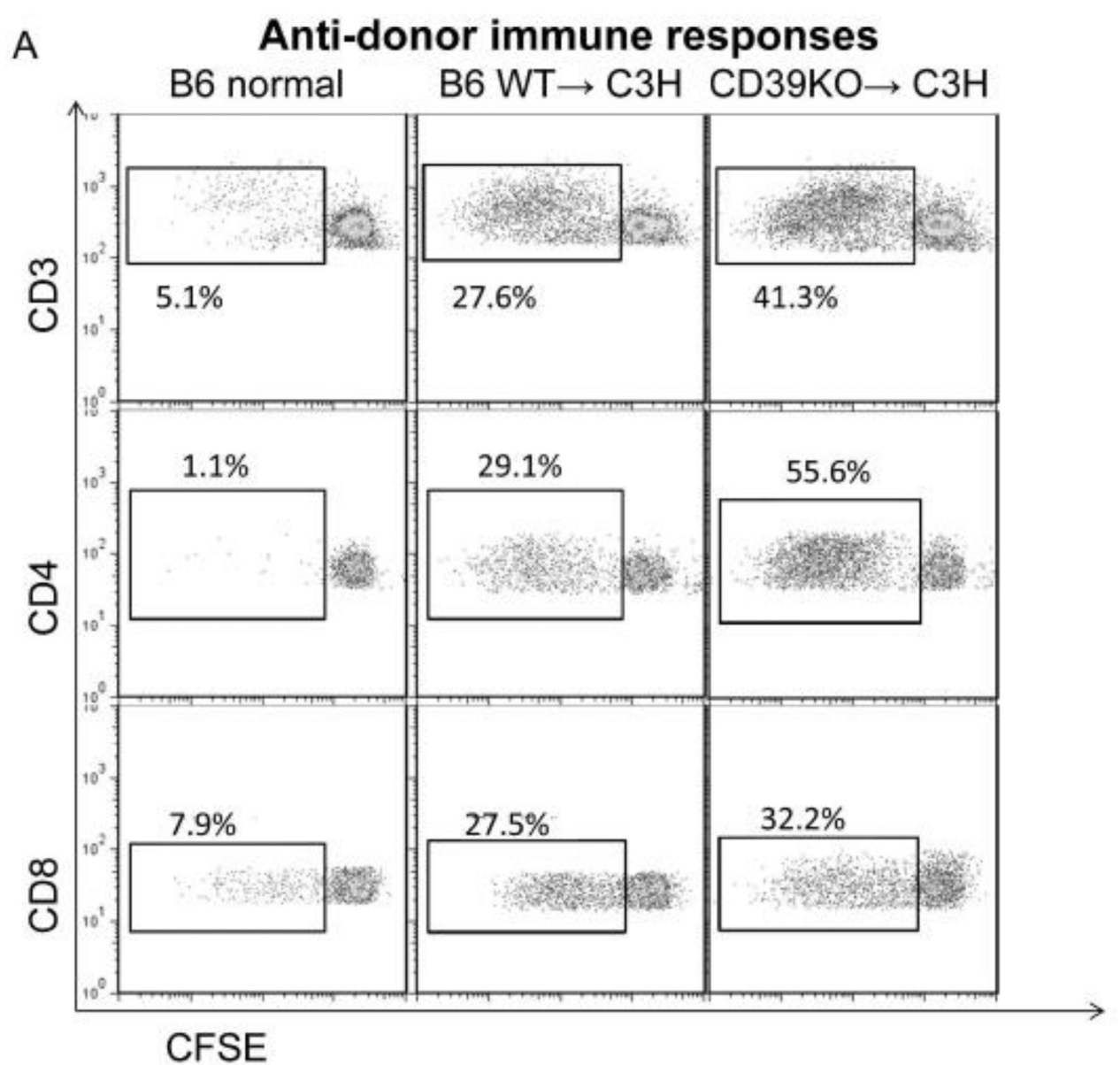

B

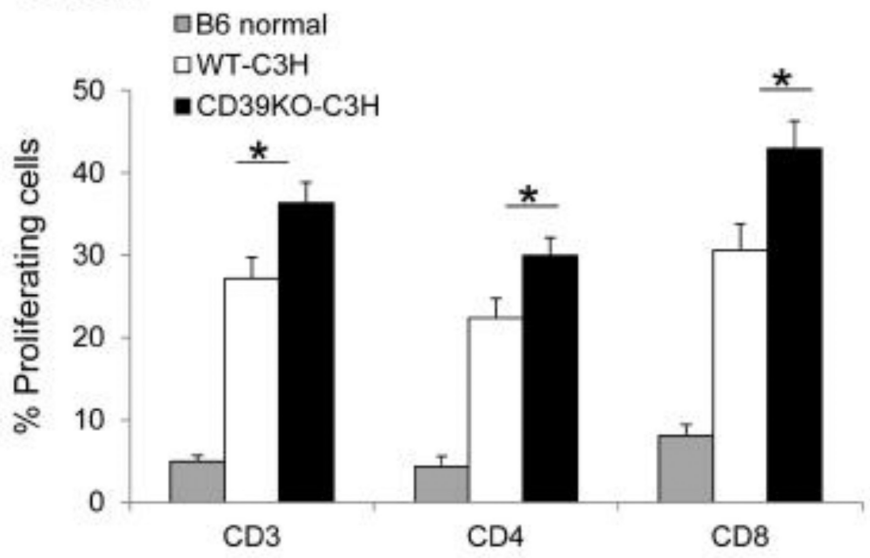

Fig. 4.

Stronger anti-donor $\mathrm{T}$ cell proliferative responses are observed in CD39KO liver transplant recipients. Splenocytes from WT or CD39KO liver transplant recipients were stimulated with donor $\mathrm{T}$ cell-depleted splenocytes in CFSE-MLR. Recipient $\mathrm{T}$ cell proliferation was determined by flow cytometry (A, B) $(n=5) ;{ }^{*} \mathrm{p}<0.05$. 


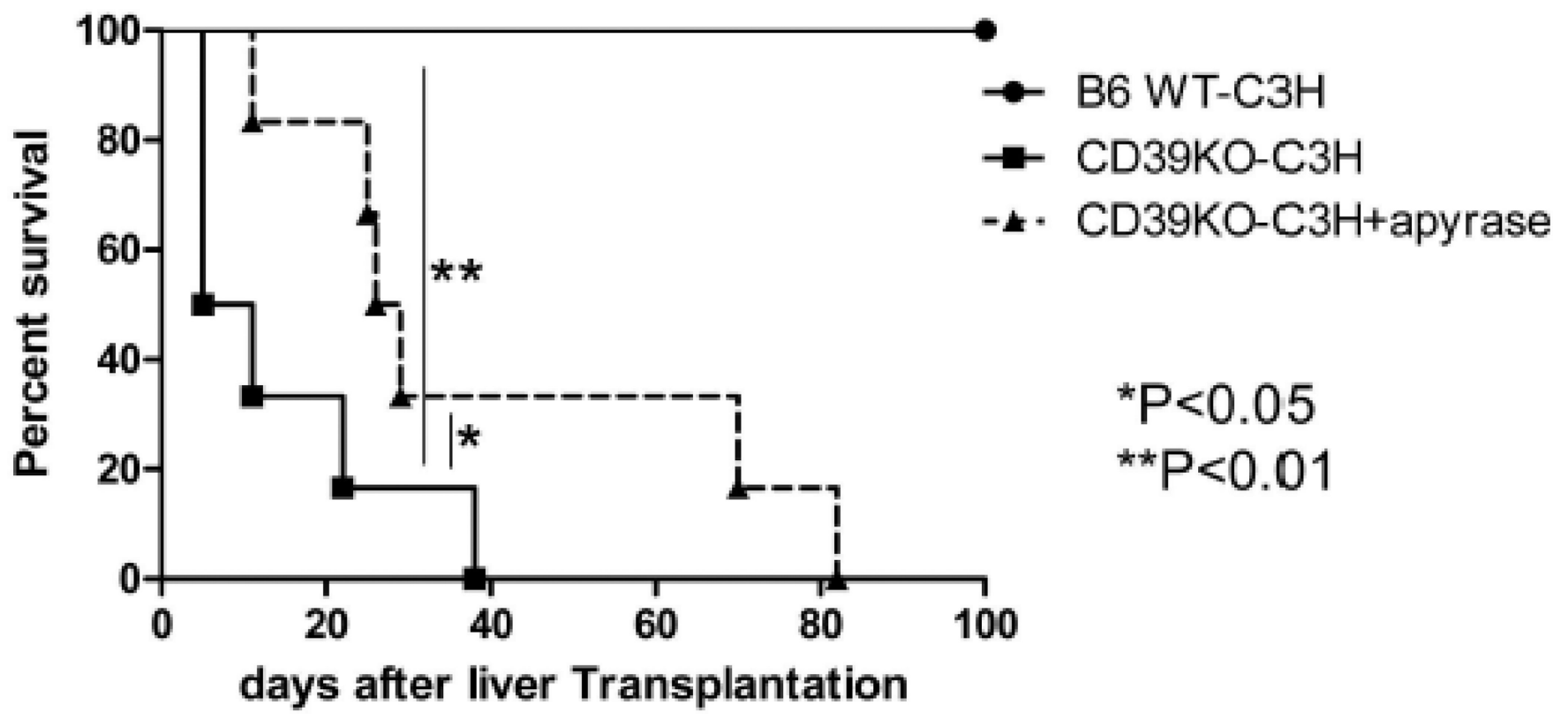

Fig. 5.

CD39KO liver allografts fail to induce tolerance, whereas soluble CD39 administration partially overcomes rejection of CD39KO grafts. Graft survival after WT B6 (n=6) or $\mathrm{CD} 39 \mathrm{KO}(\mathrm{N}=6) \mathrm{LTx}$ is shown. Apyrase was injected i.p. in one experimental group $(\mathrm{n}=6) ; * \mathrm{p}<0.01, * \mathrm{p}<0.05$. 